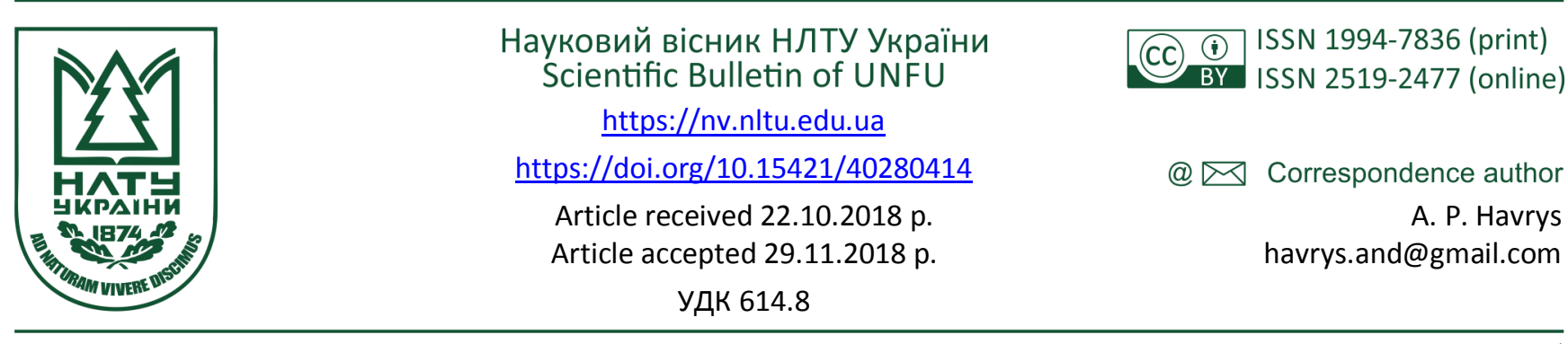

А. П. Гаврись, М. З. Лаврівський

Львівський державний університет безпеки життєдіяльності, м. Львів, Украӥна

\title{
НЕБЕЗПЕКИ ЕЛЕКТРОМОБІЛІВ І ГІБРИДНИХ ТРАНСПОРТНИХ ЗАСОБІВ
}

Проаналізовано дані про ефективність використання альтернативних джерел енергії, їхні основні переваги та недоліки. Визначено, що найпоширеніша сфера впровадження нових джерел енергії є засоби пересування, а саме: електромобілі та гібридні транспортні засоби. Наведено статистики виробництва електромобілів і гібридних транспортних засобів у світі за останні 10 років та наявність таких автомобілів в Україні. Розглянуто значення термінів "електромобіль" та "гібрид" із зображенням їхніх технологічних схем та принципу роботи. Визначено, що на сьогодні найпоширенішими $\epsilon$ літієво-іонні (Liion), нікель-метал-гідридні (NiMH) та свинцево-кислотні (PbSO4) батареї. Перелічено основні переваги та недоліки таких типів батарей і проведено їх порівняння. Розкрито основні небезпеки та ризики для рятувальників під час виконання аварійних та інших невідкладних робіт на транспортних засобах з електрорушійною силою. Зроблено висновок, що рекомендації від виробників не забезпечують послідовну, доступну та зрозумілу для рятувальників інформацію про ризики, які несе батарея чи транспортний засіб загалом. Наведено приклад окремого стандартизованого маркування транспортних засобів на електричному чи напівелектричному приводі, що ідентифікуватиме його як небезпечний з погляду високих напруг для рятувальників. Запропоновано надалі розробити уніфіковані рекомендації рятувальникам під час гасіння, рятування та виконання інших невідкладних робіт на електромобілях та гібридних транспортних засобах.

Ключові слова: електричний привід; пальне; двигун внутрішнього згорання; високовольтна батарея.

Вступ. На сьогодні рятувальники мають нові проблеми під час виконання своїх безпосередніх завдань, оскільки розвиток, впровадження та використання альтернативних джерел енергії зумовлює виникнення нових, невідомих ризиків, для яких необхідно розробляти нові методики та стратегії захисту.

Викладення осноного матеріалу. Серед найпоширеніших сфер впровадження альтернативних джерел енергії є засоби пересування. Сьогодні на транспортних засобах (Т3) використовують велику кількість альтернативних видів пального, які зображено на рис. 1.

Усі представлені джерела енергії мають переваги і недоліки. Розглянемо найпоширеніші з них.

Першою альтернативою бензину є дизельне пальне (ДП), це - основний вид пального для дизельних двигунів. Основними перевагами ДП є збільшення коефіцієнта корисної дії двигуна за більш тривалого терміну експлуатації, порівняно з бензиновим. Недоліком залишається необхідність частої та ретельної перевірки повітряного фільтра та точності кута випередження впорскування палива.

Наступним типом пального $є$ пропан або зріджений нафтовий газ. Зріджений нафтовий газ - очищений i підготовлений нафтовий газ, переведений під впливом високого тиску в рідкий стан (переважно пропан і бутан) для полегшення зберігання та перевезення (Casey, 2010). Основною перевагою є фінансова вигода, вико- ристання такого джерела енергії вдвічі вигідніше від бензинового. Щодо недоліків, то їх небагато - втрата місткості багажного відділення внаслідок розташування газового балона та невелика кількість автогазозаправних станцій у віддалених від міст районах.

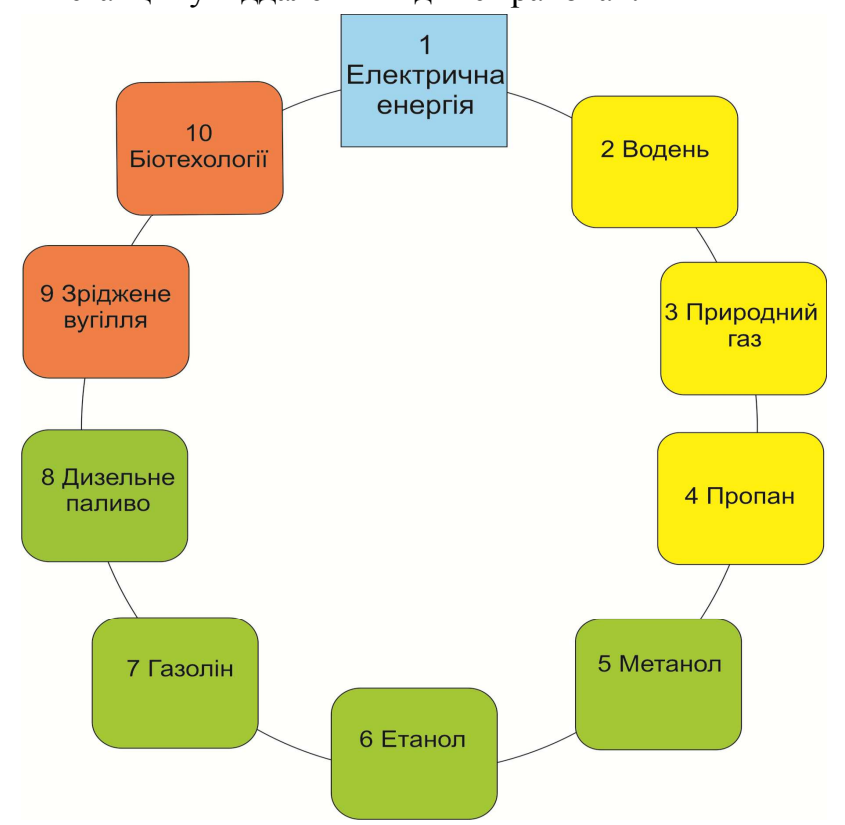

Рис. 1. Альтернативні види пального автотранспортних засобів

\section{Інформація про авторів:}

Гаврись Андрій Петрович, канд. техн. наук, викладач, кафедра цивільного захисту та комп'ютерного моделювання екогеофізичних процесів. Email: havrys.and@gmail.com; https://orcid.org/0000-0003-2527-7906

Лаврівський Мар'ян Зеновійович, викладач, кафедра цивільного захисту та комп'ютерного моделювання екогеофізичних процесів. Email: pozarnik911@gmail.com

Цитування за ДСту: Гаврись А. П., Лаврівський М. З. Небезпеки електромобілів і гібридних транспортних засобів. Науковий вісник НЛТУ України. 2018, т. 28, № 10. С. 66-70.

Citation APA: Havrys, A. P., \& Lavrivskiy, M. Z. (2018). Risks of electric and hybrid vehicles. Scientific Bulletin of UNFU, 28(10), 66-70. https://doi.org/10.15421/40281014 
Водень використовують як пальне у водневому двигуні. Двигун складається 3 двох основних частин - це паливний елемент, як первинний генератор енергії та електродвигун, який іiі використовує для зміни іiі типу (Casey, 2010). Перевагами справжнього водневого двигуна $\epsilon$ те, що він удвічі ефективніший від звичайного двигуна, абсолютно безшумний і не виділяє шкідливих газів у навколишнє середовище. Проте найбільшою перевагою є дешевизна паливних елементів водневого автомобіля. Однак у ньому існує один вагомий недолік, який відлякує багатьох автомобілістів, - небезпека вибуху установки за найменшої аварії, що також становить небезпеку для рятувальників.

Найбільшої популярності набули транспортні засоби $з$ електрорушійною системою. Окрім переваг в екологічному плані, вони мають небезпеки в разі виникнення аварій, пов'язаних із наявністю додаткового електричного обладнання (Kozyar, Rets \& Sychevsky, 2015). Оскільки ці автомобілі за зовнішніми ознаками не відрізняються від звичайних Т3, обладнаних двигунами внутрішнього згорання (ДВ3), але становлять додаткову небезпеку для працівників Державної служби України 3 надзвичайних ситуацій під час виконання рятувальних та інших невідкладних робіт, пропонуємо ввести окреме маркування для таких видів автомобілів, що полегшило б ідентифікацію та організацію ліквідації аварійної ситуації.

Згідно зі статистикою світових продажів електромобілів і гібридів (ICCT, 2018), у 2017 р. таких машин у всьому світі було реалізовано понад 3 млн одиниць. Це на 54 \% більше, ніж у 2016 р., коли покупці отримали 2 млн таких авто. У 2018 р. очікується збільшення цього показника до майже 5 млн одиниць, як показано на рис. 2, оскільки за 5 місяців 2018 р. вже продано 800 тис. Т3 з електричним приводом, що на $66 \%$ більше за аналогічний період 2017 р.

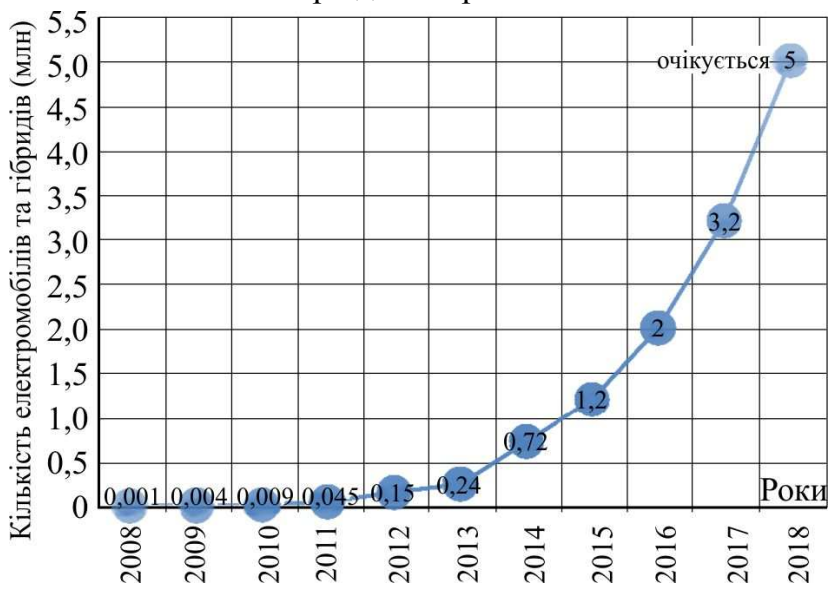

Рис. 2. Статистика продажів електромобілів та гібридів у світі за останні 10 років

3 графіку видно, що кількість електромобілів та гібридів у світі щороку зростає високими темпами. В Україні цей показник також підвищується щороку.

За статистикою (Internal Affairs, 2018), кількість зареєстрованих легкових електромобілів в Україні на 2016 р. становила 1521 од. (не враховано гібридні Т3), а на 2017 р. цей показник зріс більше, ніж у 2,5 раза і становив 3818 од., як показано на рис. 3. За 5 місяців 2018 р. кількість зареєстрованих авто на електротязі досягнула 2100 од., що більше, ніж за весь 2016 р.

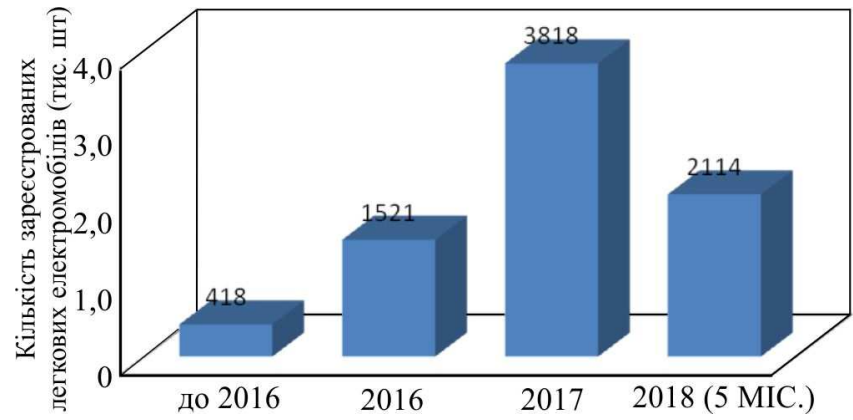

Рис. 3. Кількість зареєстрованих легкових електромобілів в Україні за роки реєстрації

Аналізуючи дані з діаграми, можемо зробити висновок, що в Україні такий вид транспорту, як електромобіль, набуває популярності та щоразу більше людей віддають перевагу автомобілям на електротязі, що потребує внесення коректив у нормативні документи, якими керуються рятувальники під час виконання своїх завдань. Прикладом цього $є$ внесення змін у розділ 2 наказу МВС України від 26.04.2018 р. № 340 "Статуту дій органів управління та підрозділів Оперативно-рятувальної служби цивільного захисту під час гасіння пожеж" під назвою "Гасіння пожеж в автомобілях 3 електричною, гібридною електричною системами приводу".

Розглянемо докладніше, які відмінності між електромобілем та гібридним Т3 та які додаткові небезпеки вони становлять.

Гібридний автомобіль (HEV - Hybrid electric vehicle) багато в чому схожий на звичайне бензинове або дизельне авто, але його привід складається 3 двигуна внутрішнього згоряння і вбудованого електродвигуна, який забезпечує певну частку потужності (рис. 4,a). Електродвигун гібрида може керувати автомобілем на низьких швидкостях, тому HEV - зазвичай це транспортний засіб з нульовим рівнем шкідливих викидів у режимі міського водіння. Електродвигун живиться від вбудованої батареї, яка заряджається у процесі роботи паливного мотора і рекуперативним гальмуванням.

Підвидом гібридного автомобіля є плагин-гібридний автомобіль, що відрізняється від гібридного можливістю зарядки від мережі. Переважно він має більшу кількість батарей і більший запас ходу на електричному приводі.

Ще одним підвидом гібридного ТЗ є автомобілі на паливних елементах. В електромобілях на паливних елементах (FCEV - Fuel cell electric vehicle) електродвигун живиться водневим паливним елементом, як зображено на рис. 4,б. У паливному елементі водень з'єднується 3 киснем, який добувають 3 повітря. Цей процес створює енергію, яка живить електродвигун. Переваги електромобілів на паливних елементах полягають у тому, що їх можна заправляти як звичайні транспортні засоби, отримуючи при цьому стандартний для паливних аналогів запас ходу.

Електромобіль BEV (Battery electric vehicle) - це автомобіль, який рухається завдяки енергії, що зберігається в акумуляторній батареї, яка живить електричний двигун рис. 4,в. Ці авто не використовує ніякого іншого палива, окрім електрики, не виробляють шкідливих викидів і їх вважають найбільш екологічно чистим транспортом на сьогодні.

Основним агрегатом усіх перелічених вище Т3 3 електричним та гібридним приводом $є$ електрохімічна 
батарея. 3 розвитком електрокарів типи та конфігурації батарей змінювалися. На сьогодні найпоширенішими є літієво-іонні (Li-ion), нікель-метал-гідридні (NiMH) та

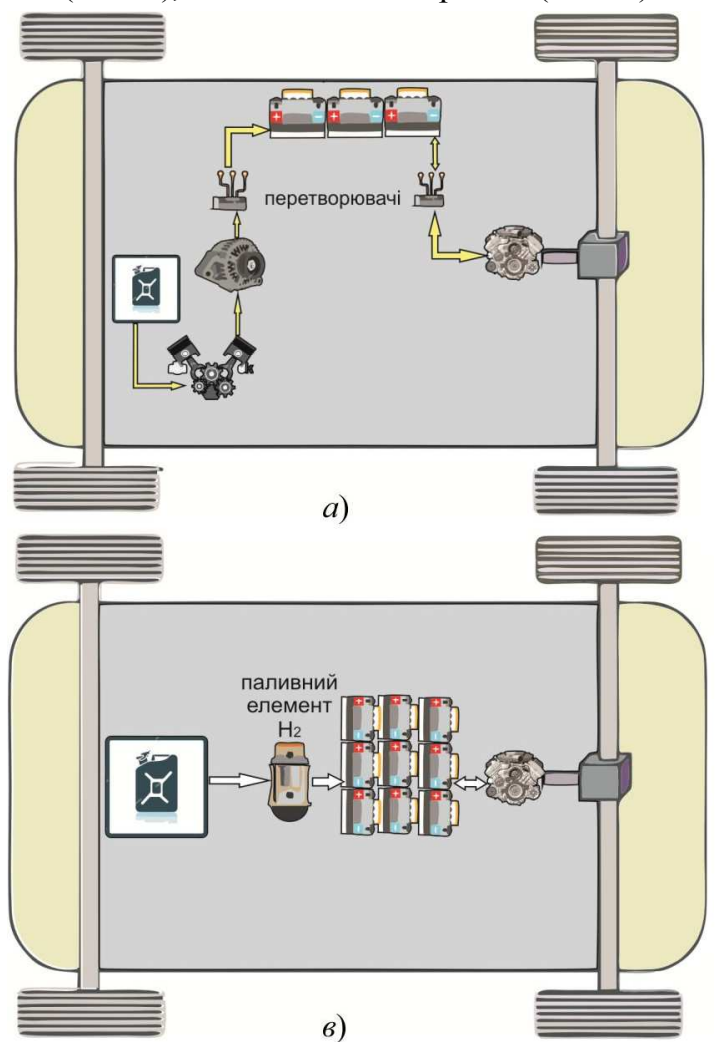

Табл. 1. Марки електромобілів та гібридів (ранжовані за роком випуску) з наведенням типу батареї

\begin{tabular}{|c|c|c|}
\hline Марка машини & Рік випуску & Тип батареї \\
\hline \multicolumn{3}{|c|}{ Електромобілі } \\
\hline BMW i3 & 2018 & Li-ion \\
\hline Kia Soul EV & 2018 & Li-ion \\
\hline Nissan Leaf & 2018 & Li-ion \\
\hline Tesla Model 3 & 2017 & Li-ion \\
\hline Volkswagen e-Golf & 2017 & Li-ion \\
\hline Renault ZOE Z. E. 40 & 2017 & Li-ion \\
\hline Ford Focus Electric & 2017 & Li-ion \\
\hline Opel Ampera-e & 2017 & Li-ion \\
\hline Tesla Model X & 2016 & Li-ion \\
\hline Chevrolet Bolt & 2016 & Li-ion \\
\hline Hyndai Ioniq Electric & 2016 & Li-ion \\
\hline Honda Fit EV & 2013 & Li-ion \\
\hline Fiat 500e & 2013 & Li-ion \\
\hline Volkswagen e-Up! & 2013 & Li-ion \\
\hline Tesla Model S & 2012 & Li-ion \\
\hline Byd E6 & 2011 & Li-ion \\
\hline Citroen C-Zero & 2010 & Li-ion \\
\hline \multicolumn{3}{|c|}{ Гібриди } \\
\hline BMW i8 Roadster & 2018 & Li-ion \\
\hline Range Rover Sport Hybrid P400e & 2018 & Li-ion \\
\hline Toyota Prius Prime & 2017 & Li-ion \\
\hline Hyundai Ioniq Plug-in Hybrid & 2017 & Li-ion \\
\hline Nissan Rogue Hybrid & 2017 & Li-ion \\
\hline Toyota Highlander Hybrid & 2017 & Ni-MH \\
\hline BMW 740e xDrive iPerformance & 2016 & Li-ion \\
\hline Volvo S90 T8 PHEV & 2016 & Li-ion \\
\hline Kia Niro Hybrid & 2016 & Li-ion \\
\hline Mitsubishi Outlander & 2016 & Li-ion \\
\hline Audi Q7 e-tron Quattro & 2016 & Li-ion \\
\hline Lexus RX 450h Hybrid & 2016 & Ni-MH \\
\hline Toyota RAV4 Hybrid & 2015 & Li-ion \\
\hline Chevrolet Tahoe Hybrid & 2015 & Ni-MH \\
\hline Volvo XC T8 PHEV & 2015 & Li-ion \\
\hline Audi A3 Sportback e-tron & 2014 & Li-ion \\
\hline Ford Escape Hybrid & 2012 & Ni-MH \\
\hline Honda Civic Hybrid & 2011 & Ni-MH \\
\hline
\end{tabular}

свинцево-кислотні $\left(\mathrm{PbSO}_{4}\right)$ батареї. У табл. 1 представлено найсучасніші Т3 з типом батарей, які в них використовуються.

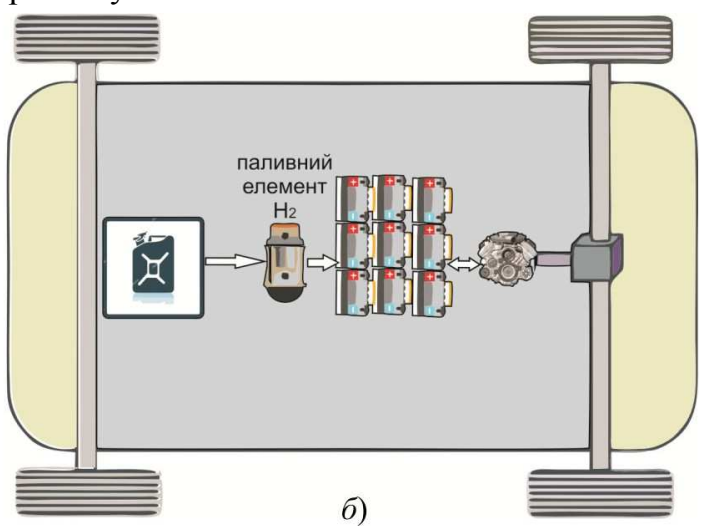

Рис. 4. Схематичне розташування основних вузлів: a) гібридного ТЗ; б) гібридного ТЗ на паливних елементах; в) електромобіля

Кожна 3 цих трьох технологій має свої переваги та недоліки у вартості, часі зарядки, критичній температуpi нагрівання, системі охолодження та інших характеристик. Окрім цього, усі вони несуть унікальні загрози для рятувальників під час гасіння таких типів Т3 (Havrys \& Skrupka, 2018). Основні переваги та недоліки цих трьох типів батарей показано в табл. 2.

Табл. 2. Переваги та недоліки основних типів батарей електромобілів та гібридів

\begin{tabular}{|c|c|c|}
\hline $\begin{array}{c}\text { Тип } \\
\text { батареї } \\
\end{array}$ & Переваги & Недоліки \\
\hline $\begin{array}{c}\text { Свинцево- } \\
\text { кислотна } \\
\left(\mathrm{PbSO}_{4}\right) \\
\end{array}$ & $\begin{array}{l}\text { • низька початкова } \\
\text { вартість }\end{array}$ & • короткий життєвий цикл; \\
\hline $\begin{array}{c}\text { Нікель- } \\
\text { метал- } \\
\text { гідридна } \\
\text { (NiMH) }\end{array}$ & $\begin{array}{l}\text { - висока та середня } \\
\text { щільність енергії; } \\
\text { в використання без- } \\
\text { печних матеріалів; } \\
\text { стабільна вихідна } \\
\text { потужність }\end{array}$ & $\begin{array}{l}\text { в висока початкова вар- } \\
\text { тість; } \\
\text { швидко саморозря- } \\
\text { джається; } \\
\text { погано працює за низь- } \\
\text { ких температур; } \\
\text { високі вимоги до охоло- } \\
\text { дження } \\
\end{array}$ \\
\hline $\begin{array}{c}\text { Літієво- } \\
\text { iонна } \\
\text { (Li-ion) }\end{array}$ & $\begin{array}{l}\bullet \text { висока щільність } \\
\text { енергії; } \\
\text { • низька швидкість } \\
\text { саморозрядки; } \\
\text { • добре працює за } \\
\text { низьких температур }\end{array}$ & $\begin{array}{l}\text { • висока початкова вар- } \\
\text { тість; } \\
\text { • відсутність довговічних } \\
\text { експлуатаційних характе- } \\
\text { ристик }\end{array}$ \\
\hline
\end{tabular}

Для прикладу свинцево-кислотні батареї забезпечують вищу потужність автомобіля, але 3 коротшим життєвим циклом, ніж інші батареї. Деякі недоліки перекривають низку переваг - вага нікель-метал-гідридної батареї значно вища від літієвої, хоча продуктивність іiі більша завдяки більшій ємності, або низька швидкість саморозрядки, що не потребує частої заміни літієво-іонних батарей, заперечуючи високу початкову 
вартість. Загальний вигляд нікель-метал-гідридної та літієво-іонної батареї зображено на рис. 5.
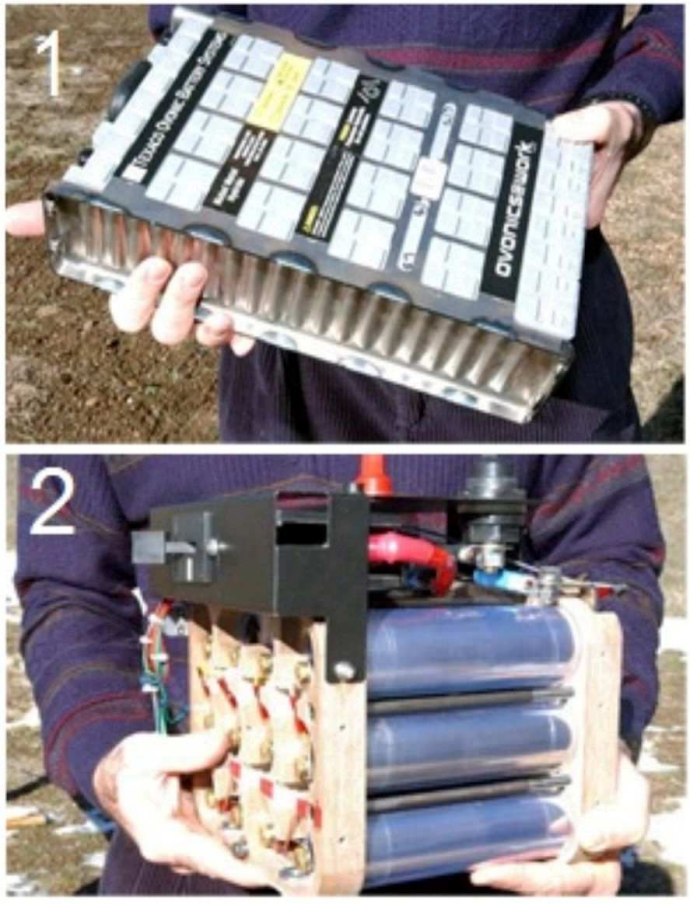

Рис. 5. Загальний вигляд нікель-метал-гідридної (1) та літієвоіонної батареї (2) (Casey, 2010)

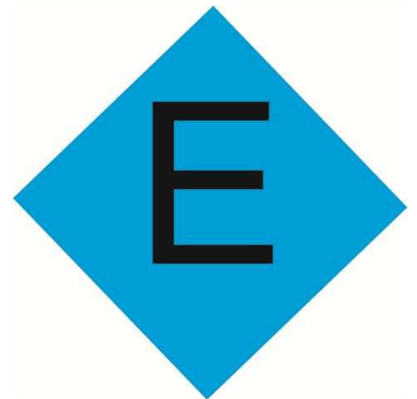

Рис. 6. Запропонований варіант знаку маркування електромобілів та гібридів

Кожен вид електричних батарей має певні рекомендації для рятувальників під час поводження з ними. Залежно від інциденту, що трапився (пожежа, деформація корпусу, затоплення автомобіля), повинні бути розроблені уніфіковані рекомендації та маркування для таких видів Т3 з трьома типами батарей, оскільки література виробника не забезпечує послідовну, доступну та зрозумілу для рятувальників інформацію про ризики, які неce батарея чи транспортний засіб загалом (Ruzhitsky \& Loik, 2017; Haiduk, 2016). Окрім цього, потрібно врахувати тип автомобіля, а саме наявність пального для плагин-гібридів чи водню для електромобілів на паливних елементах (Kovalchuk, Loik \& Lozinsky, 2014).

Для прикладу, літієво-іонна (Li-ion) батарея, яку найчастіше використовують в електромобілях, може вибухнути, якщо на неї подати занадто високе навантаження або від виробничого браку, що може призвести до запалення суміші газів і самозаймання автомобіля
(Dunbar, 2005; Havrys \& Skrupka, 2018). Тому насамперед вважаємо, що потрібно розробити і впровадити маркування Т3 з електричним типом приводу, що ідентифікуватиме його, як небезпечний з погляду високих напруг для рятувальників під час виконання рятувальних та інших невідкладних робіт. На наша думку, це має бути квадрат, повернений на $45^{\circ}$ (форма ромба) розміром $100 \times 100$ мм, із фоном голубого кольору та великою літерою Е чорного кольору, як зображено на рис. 6.

\section{Висновки:}

- проаналізовано статистику виробництва транспортних засобів на електричному чи напівелектричному приводі в Україні та світі;

- проаналізовано та обгрунтовано небезпеки та ризики, які несуть свинцево-кислотні $\left(\mathrm{PbSO}_{4}\right)$, нікель-метал-гідридні (NiMH) та літієво-іонні (Li-ion) батареї;

- запропоновано впровадити окреме маркування для Т3 на електричному чи напівелектричному приводі за наведеним варіантом;

- запропоновано надалі розробити уніфіковані рекомендації рятувальникам під час гасіння, рятування та виконання інших невідкладних робіт на електромобілях та гібридних ТЗ.

\section{Перелік використаних джерел}

Casey, C. Grant. (2010). Fire Fighter Safety and Emergency Response for Electric Drive and Hybrid Electric Vehicles, USA, 135 p. [In Ukrainian].

Dunbar, Ya. (2005). The technique of salvation from cars. Netherlands: Holmatro indust Equipment, 255 p. [In Russian].

Haiduk, M. O. (2016). On the issue of extinguishing fires and eliminating the consequences of an accident involving electric cars and hybrid cars. The theory and practice of extinguishing fires and eliminating emergencies, (pp. 33-35). Cherkasy, AFSU. [In Ukrainian].

Havrys, A. P., \& Skrupka, A. V. (2018). Features of the extinguishing and protection of rescuers in the fire in the electric vehicle. Problems and prospects of labor protection development, (pp. 84-85). Lviv: LSU LS. [In Ukrainian].

Havrys, A. P., \& Skrupka, A. V. (2018). Increasing the competence of rescuers for the elimination of accidents involving electric vehicles within the framework of official training. Actual questions of technogenic and civil security of Ukraine, (pp. 141-143). Nikolaev: NUK. [In Ukrainian].

ICCT. (2018). Official website of the International Clean Air Transportation Agency (The International council on clean transport). Retrieved from: https://www.theicct.org/

Internal Affairs. (2018). Official site of the Ministry of Internal Affairs of Ukraine. Retrieved from: http://mvs.gov.ua/.

Kovalchuk, V. M., Loik, V. B., \& Lozinsky, Yu. R. (2014). Improvement and implementation of emergency rescue operations in response to road accidents. Visnuk LSU LS, 9, 7-13. [In Ukrainian].

Kozyar, B. O., Rets, R. A., \& Sychevsky, M. I. (2015). Analysis of the dangers caused by a hybrid vehicle in the event of a road accident following his participation. Problems and prospects for the development of safety of viability, (pp. 127-128). Lviv: LSU LS. [In Ukrainian].

Ruzhitsky, D. V., \& Loik, V. B. (2017). Organization of emergency rescue works with hybrid vehicles. Problems and prospects for the development of safety of viability, (pp. 88-90). Lviv: LSU LS. [In Ukrainian].

А. П. Гаврись, М. З. Лавривский Львовский государственный университет безопасности жизнедеятельности., г. Львов, Украина

\section{ОПАСНОСТИ ЭЛЕКТРОМОБИЛЕЙ И ГИБРИДНЫХ ТРАНСПОРТНЫХ СРЕДСТВ}

В работе проанализированы данные об эффективности использования альтернативных источников энергии, их основные преимущества и недостатки. Определено, что самая распространенная сфера применения новых источников энергии является средства передвижения, а именно электромобили и гибридные транспортные средства. Приведенная статистика производства электромобилей и гибридных транспортных средств в мире за последние 10 лет и наличие таких автомобилей в Ук- 
раине. Раскрыто значение терминов "электромобиль" и "гибрид" с изображением их технологических схем и принципа работы. Определено, что на сегодня наиболее распространены литиево-ионные (Li-ion), никель-металл-гидридные (NiMH) и свинцово-кислотные (PbSO4) батареи. Перечислены основные преимущества и недостатки таких типов батарей и проведено их сравнение. Раскрыты основные опасности и риски для спасателей при выполнении аварийных и других неотложных работ на транспортных средствах с электродвижущей силой. Сделан вывод, что рекомендации от производителей не обеспечивают последовательную, доступную и понятную для спасателей информацию о рисках, которые несет батарея или транспортное средство в целом. Приведен пример отдельной стандартизированной маркировки транспортных средств на электрическом или полуэлектрическом приводе что будет идентифицировать его, как опасный с точки зрения высоких напряжений для спасателей. Предложено в дальнейшем разработать унифицированные рекомендации спасателям при тушении, спасении и проведении других неотложных работ на электромобилях и гибридных транспортных средствах.

Ключевые слова: электрический привод; горючее; двигатель внутреннего сгорания; высоковольтная батарея.

A. P. Havrys, M. Z. Lavrivskiy Lviv State University of Life Safety, Lviv, Ukraine

RISKS OF ELECTRIC AND HYBRID VEHICLES

Today, rescuers are exposed to new threats in fulfilling their immediate tasks, as the development, implementation and use of alternative energy sources lead to the emergence of new, unfamiliar risks, for which new methods and strategies of protection need to be developed. In the article, efficiency data of the use of alternative energy sources, their main advantages and disadvantages were analysed. The most widespread sphere of introduction new energy sources for the means of transportation, namely electric and hybrid vehicles were determined. The production statistics of electric and hybrid vehicles in the world for the last 10 years and the availability of such cars in Ukraine were given. The data showed that the number of electric cars and hybrids in the world and in our country has increased almost twice in recent years. The meaning of the terms "electric car" and "hybrid" with the representation of their technological schemes and the principle of work were revealed. The ranks of the car brands and battery types used in them ranked by years were shown. Today the most common lithium-ion ( $\mathrm{Li}$-ion), nickel-metal hydride (NiMH) and lead-acid (PbSO4) batteries were determined. The main advantages and disadvantages of these types of batteries were listed and compared. The main hazards and risks for rescuers during emergency and other urgent work on vehicles with electromotive force were revealed. It is concluded that the manufacturer's recommendations do not provide consistent, accessible and understandable to rescuers information on the risks borne by the battery or the vehicle as a whole. An example of a separate, standardized marking of vehicles on an electric or semi-electric drive that identifies it as dangerous from the point of view of high voltages for rescuers was given. Further development of unified recommendations for rescuers during extinguishing, rescuing and carrying out other urgent works on electric and hybrid vehicles was proposed.

Keywords: electric drive; fuel; internal combustion engine; high-voltage battery. 